Modern Asian Studies 51, 2 (2017) pp. 432-461. (C) Cambridge University Press 2017 doi:10.1017/Soo26749X16000408

\title{
Caste and its Histories in Colonial India: A reappraisal*
}

ROSALIND O'HANLON

\author{
Faculty of Oriental Studies, University of Oxford, United Kingdom \\ Email: rosalind.ohanlon@orinst.ox.ac.uk
}

\begin{abstract}
David Washbrook's influential early work on South India set the terms for much subsequent debate about caste, with its exploration of the key role of the colonial state in shaping caste ideologies and institutions. Over subsequent decades, historians and anthropologists have come increasingly to emphasise the 'colonial construction' of caste and its enduring legacies in post-colonial India. Yet there were also significant continuities linking the forms of colonial caste with much earlier regional histories of conflict and debate, whose legacies can be traced into the late colonial period. In particular, the juxtaposition between Brahman and non-Brahman itself was anticipated in a tradition of conservative social commentary that emerged in the Deccan Sultanate state of Ahmadnagar, and came to circulate widely through Banaras and western India during the seventeenth and eighteenth centuries. This tradition of commentary acquired new salience during the nineteenth century. It entered the colonial archive as an authoritative source of knowledge, and also provoked early 'non-Brahman' intellectuals into a fresh engagement with its conservative social vision. In their attempts to rebut this vision, these intellectuals displayed a detailed knowledge of its social history and a deep familiarity with the judicial decisions through which it had been upheld in earlier centuries.
\end{abstract}

\section{Caste, state, and society: shifting perspectives}

David Washbrook was an early and very important contributor to studies of the history of caste under colonialism. When he embarked on his study of Madras Presidency, caste was almost universally perceived as an unchanging inheritance of the pre-colonial tradition. One of the signal achievements of his work has been to locate the caste

* I thank the three anonymous reviewers of this article for their valuable suggestions as to how to improve and clarify the arguments here. All errors are my own. 
institutions of South India within their different agrarian as well as urban contexts, and to trace the ways in which both colonial economic impacts and initiatives of the state reshaped these institutions. ${ }^{1}$ With Christopher Baker, Washbrook was also one of the earliest scholars to draw attention to the impact of the Indian government's decennial census reports, new methods of public communication, and policies of reservation in stimulating the rise of caste associations, bringing together sub-castes which had hitherto emphasized their separation into larger and often supra-regional collectives. ${ }^{2}$ Along with the work of his contemporaries, Eugene Irschick, Marguerite Ross Barnett, and Christopher Baker, Washbrook's study posed new and provocative questions, and provided some, at least, of the answers. ${ }^{3}$ Since then, his work has ranged very widely. He has explored fundamental aspects of colonial law and property rights and traced the place of South India in the global economy from the early modern period to the present. He has looked back to the eighteenth-century formation of many South Indian institutions, and forward to explain the forces that have made present-day South India into India's economic and educational powerhouse.

This article returns to two of the perspectives that have particularly marked Washbrook's work: his concern with colonial caste and his interest in uncovering the early modern antecedents of some key nineteenth-century Indian social and political institutions. It does so both because his contribution here was so significant, and because caste in its many forms has remained such a continuing challenge and conundrum in India's present society. Washbrook brought out his first monograph and essays in the mid-1970s, just a few years after the publication of Louis Dumont's Homo Hierarchicus. ${ }^{4}$ Washbrook's work on caste in South India was very much a study of local social and political history, rather than an attempt at a larger social theory. Both, of course, entered a field already rich in studies of caste from

${ }^{1}$ David Washbrook, The Emergence of Provincial Politics: the Madras Presidency I87o1920. Cambridge: Cambridge University Press, 1976.

${ }^{2}$ C.J. Baker and D.A. Washbrook, South India: political institutions and political change, I880-1940. Delhi: Macmillan, 1975 .

${ }^{3}$ Eugene Irschick, Politics and Social Conflict in South India: the Non-Brahman Movement and Tamil Separatism I9I6-I929. Berkeley: University of California Press, 1969; Marguerite Ross Barnett, The Politics of Cultural Nationalism in South India. Princeton: Princeton University Press, 1976; Christopher Baker, The Politics of South India. Cambridge: Cambridge University Press, 1976.

${ }^{4}$ Louis Dumont, Homo Hierarchicus: the caste system and its implications. London: Weidenfeld and Nicolson, 1970. 
a variety of different perspectives, including those of anthropology, Indology, sociology, and Marxist history. Although widely influential, Dumont's work was also the subject of significant scholarly reservation. Critics objected particularly to his depiction of the all-pervasive and 'encompassing' nature of the values of purity and pollution within Hindu Indian society, and the apparent absence of solid contextual evidence for his model. ${ }^{5}$ In this setting, social historical studies of caste such as that of Washbrook, and the model of Dumontian sociology, seemed to emerge out of entirely different intellectual frameworks.

From the mid-1980s, the two moved more closely together. Drawing on the perspectives opened up by Edward Said's analysis of the intellectual heritage of Indology and of colonial knowledge-gathering, Appadurai, Inden, Cohn, Dirks, and others from the Chicago School argued that Dumont's was a quintessentially 'Orientalist' view, which understood Indian society to be derived from caste as a single unchanging essence, itself described in the works of classical Indology. What Dumont was seeing was actually caste after its transformation in the era of colonialism. Here, Brahmans had been recruited as authoritative guides to the Hindu social order, other axes of power such as that of kingship had been emptied of real meaning, and initiatives of the colonial state such as its census operations and its schemes of positive discrimination in favour of 'backward' communities impelled colonial subjects to identify, and to organize themselves, principally in terms of caste. ${ }^{6}$ In this context, the prescience of Washbrook's work on the role of the colonial state in shaping caste political organization became sharply apparent. These developments moved the debate very much towards the colonial shaping of caste, and away from its eighteenth century and older histories. If anything, the very success of

\footnotetext{
${ }^{5}$ See, for example, reviews by G.J. Fuller in Modern Asian Studies 5, 4 (1971): pp. 405-o6; McKim Marriott in American Anthropologist 71, 6 (1969): pp. 1 16-75; R.S. Khare in Journal of Asian Studies 30, 4 (1971): pp. 859-68, and the scholars who contributed to the critiques in T.N. Madan (ed.), 'On the nature of caste in India: a symposium' in Contributions to Indian Sociology 5, 1 (1971).

${ }^{6}$ Edward Said, Orientalism. New York: Pantheon, 1978; Arjun Appadurai, 'Is Homo Hierarchicus?' in American Ethnologist 13, 4 (1986): pp. 745-61; Ronald B. Inden, Imagining India. Oxford: Basil Blackwell, 1990; Bernard Cohn, Colonialism and Its Forms of Knowledge. Princeton: Princeton University Press, 1996; and Nicholas B. Dirks, Castes of Mind: colonialism and the making of modern India. Princeton: Princeton University Press, 2001. The best synoptic assessment of these processes remains Susan Bayly, Caste, Society and Politics in India from the Eighteenth Century to the Modern Age. Cambridge: Cambridge University Press, 1999.
} 
these 'post-colonial' critiques reinforced the turn away from the precolonial, in their suggestion that our understandings of older historical periods were likely to be the tainted legacies of colonial knowledge.

Scholarship since the 1990 s has focused even more firmly on more recent changes in the form and significance of caste. ${ }^{7}$ The market liberalization of the 1990 s helped bring new and aspirant middle classes into being, opened avenues of social mobility out of 'traditional' occupations for many, and gradually reduced the significance of the village as a social focus. The affirmative action programme of the Mandal Commission, progressively implemented from 1990, identified 'Other Backward Classes' as a new caste category in need of their own quota of reservations in government employment and education. The 'Mandalization' of Indian politics has brought new caste solidarities and political alliances into being under the 'Other Backward Classes' label, some of which have made common cause with Dalit parties. Regional parties across India have in turn drawn strength from these new collectives. The rising power of Hindu nationalist parties from the 1990 s likewise deeply affected caste in political discourse and social life. Although the Bharatiya Janata Party and its affiliates provided an outlet for upper-caste resentments against Mandal, the Party nonetheless lent its support in principle to affirmative action.

As many observers have now noted, therefore, caste in contemporary India has continued to develop away from its 'traditional' form as ritual, hierarchy, and daily observance. It finds public legitimacy and visibility instead in the political and judicial fields of public life. It is visible in India's very widespread state-sponsored programmes of positive discrimination, and in the development of what are now termed 'ethnicized' regional caste communities through which 'Other Backward Classes' and Dalits have found new means of political mobilization. ${ }^{8}$ Caste in this new setting has continued to attract close scholarly scrutiny. At the local level, caste and class disadvantage deeply affect everyday contact with agents of the state. A fresh class of political entrepreneurs-'naya netas', often men of Other Backward Class or Dalit backgrounds-have emerged as intermediaries between

\footnotetext{
${ }^{7}$ For an overview, see Stuart Corbridge, John Harriss and Craig Jeffrey, 'Does Caste Still Matter in India?'. In Stuart Corbridge et al. (eds), India Today: Economy, Politics and Society. Cambridge: Polity Press, 2013, pp. 239-57.

${ }^{8}$ Good treatments of these broad themes are in Surinder Jodhka (ed.), 'Caste matters' in Seminar, Special issue, 633, May (2012). See also the important treatment in C.J. Fuller (ed.), Caste Today. Delhi: Oxford University Press, 1996, pp. 1-31.
} 
the village and the state, replacing older patron-client dependencies. ${ }^{9}$ At broader levels, as Christophe Jaffrelot and many others have suggested, the large Other Backward Classes political combines of the 1990 are now - in many Indian states — giving way to individual castes or jatis, and state-level parties now rest increasingly on the political mobilization of a single caste. This makes the coalition-building of the all-India parties infinitely more challenging, reinforcing the drift of power away from central government and towards India's states. ${ }^{10}$ Dalit parties have likewise transformed the potential of caste as a vehicle for mobilization, combining the assertion of new political identities with attempts to build broad anti-caste alliances within and across India's states. ${ }^{11}$ Once deemed an immoveable part of India's political architecture since the linguistic reorganization of states in 1956, state boundaries are now once again open to successful campaigns for their redrawing, in part as a consequence of state-level movements of caste assertion. ${ }^{12}$ Many scholars have described the force and pride with which large and small caste communities throughout India now assert their histories, identities, and legitimate political rights and expectations. Puranic texts, oral traditions, sectarian histories, colonial ethnographies, archaeological records, and sacred geographies furnish the political energy for these modern caste identities, providing a remarkably effective basis for political cohesion, the mobilization of community resources, and

\footnotetext{
${ }^{9}$ There is a large literature here, but see in particular Stuart Corbridge et al., Seeing the State: governance and governmentality in India. Cambridge: Cambridge University Press, 2005; Anirudh Krishna, 'Politics in the Middle: mediating relationships between the citizens and the state in rural north India'. In Herbert Kitschelt and Steven I. Wilkinson, Patrons, Clients and Policies: patterns of democratic accountability and political competition. Cambridge: Cambridge University Press, 2007, pp. 141-58.

${ }^{10}$ These processes are well described in Christophe Jaffrelot, Region, Caste and Politics in India. New York: Columbia University Press, 2011.

${ }^{11}$ Some good recent regional studies are Anupama Rao, The Caste Question: Dalits and the politics of modern India. Berkeley and Los Angeles: University of California Press, 2009; Badri Narayan, The Making of the Dalit Public in North India: Uttar Pradesh, I95o to the present. Delhi: Oxford University Press, 201 1; Hugo Gorringe, Untouchable Citizens: Dalit movements and democratisation in Tamilnadu. New Delhi: Sage Publications, 2005; Sohini Guha, 'From ethnic to multi-ethnic: the Bahujan Samaj Party in north India' in Ethnopolitics 1 2, 1 (2013): pp. 1-29.

${ }^{12}$ Asha Sarangi and Sudha Pai (eds), Interrogating Reorganisation of States: culture, identity and politics in India. London: Routledge, 2011 ; Louise Tillin, Remapping India: new states and their political origins. London: Hurst and Co., 2013.
} 
adaptability to the varying circumstances of state-level political competition. $^{13}$

\section{Family, gender, and the reproduction of caste in liberal India}

This striking energization of caste in politics and public life has brought not only new confidence but new political leverage, most often to communities who had earlier struggled for political influence and resources. Yet these developments have in turn brought their own problems, particularly in the context of liberalized India. The contraction of the state, the move of middle-income groups increasingly to private provision in education and health, and the emergence of a small 'creamy' layer of Other Backward Classes and Dalit middle classes has deepened social inequality. In turn this has created political tensions between Other Backward Classes and Dalits as often as political solidarities. Even in the form of larger regional combines, caste continues to be more significant in accentuating social and economic deprivation than in offering tools for combating them. This is so for three principle reasons. First, and most obviously, the practice of caste endogamy remains the norm rather than the exception. As very many historians and social anthropologists have noted, this gives caste a close connection with the reproduction of class difference. Material wealth, educational advantage, occupational experience, and social connections are passed on within family and caste community, enabling new generations to make the transition from older forms of landed privilege to urban professional competencies. ${ }^{14}$

Second, caste retains enormous social force in the realm of belief and affect. Family, community, and many areas of religious practice are home not only to caste as apprehended cultural difference, but to

\footnotetext{
${ }^{13}$ See in particular Dipankar Gupta (ed.), 'The certitudes of caste: when identity trumps hierarchy' in Contributions to Indian Sociology, Special issue, 38, 1-2, JanuaryAugust (2004). For a superb regional discussion of North India's Yadava communities, see Lucia Michelutti, The Vernacularisation of Democracy. Politics, caste and religion in India. London: Routledge 2008.

${ }^{14}$ There is a very large literature here. Some outstanding regional studies are: C.J. Fuller and Haripriya Narasimhan, Tamil Brahmans: the making of a middle class caste. Chicago: University of Chicago Press, 2014; C. Jeffrey, P. Jeffrey and R. Jeffrey, Degrees Without Freedom: education, masculinities and unemployment in North India. Stanford: Stanford University Press, 2008; Amita Bhaviskar and Raka Ray (eds), Elite and Everyman: the cultural politics of the Indian middle class. New Delhi: Routledge, 2011.
} 
caste as hierarchy, disowned in public while assiduously maintained in private. M.S. Pandian, Ramesh Bairy, and Adheesh Sathaye have all described Brahman private life as a domain where a sense of Brahman uniqueness is preserved, arising out of long-established personal and spiritual disciplines, which are readily translatable into success in the world of bureaucracy and the professions, while defended at home as intimate practices of personal life which are part of cultural heritage. ${ }^{15}$ James Manor and many others have noted that it is much more difficult for powerful rural castes to exert control in many mundane social relationships. ${ }^{16}$ At the same time, however, as Diana P. Mines and many others have noted, purity and prestige on public religious occasions such as temple festivals are still intimately tied up with dominant caste status. ${ }^{17}$

Third, caste as hierarchy is also reproduced in the domain of gender. While the persistence of gender inequalities in India has long been a focus of attention, their essential link with the maintenance of caste hierarchies has not always been sufficiently appreciated. Hypergamous or anuloma - 'with the hair'-marriage, in which women marry men who are their social equals or superiors, has historically been a core principle of dharmic Hinduism. It is connected with the belief that at marriage, a wife takes on her husband's identity and substance. From this perspective, an anuloma marriage preserved or enhanced the worth of a woman and consequently that of her family. A pratiloma'against the hair'-marriage, in which a woman married a man of lesser status, simply degraded the woman and her family, while doing nothing to raise the status of the man. Hypergamy was also connected with the belief in dharmic Hinduism that the most virtuous form of marriage was that of kanyādān, a father's 'gift' of a suitably decked and ornamented girl to her husband's family and, among the least virtuous, a marriage in which a father took money or bride-price in exchange for the woman. ${ }^{18}$ The gradual displacement of bridewealth

\footnotetext{
${ }^{15}$ See in particular M.S.S. Pandian, Brahmin and Non-Brahmin: geneaologies of the Tamil political present. Ranikhet: Permanent Black, 2007, pp. 61-101; Ramesh Bairy T.S., Being Brahmin, Being Modern: exploring the lives of caste today. New Delhi: Routledge, 2010; Adheesh Sathaye, Crossing the Lines of Caste: Viśämitra and the construction of Brahmin power in Hindi mythology. New York: Oxford University Press, 2015.

${ }^{16}$ James Manor, 'Prologue: Caste and Politics in Recent Times'. In Rajni Kothari (ed.), Caste in Indian Politics. Delhi: Orient Longman, 201 1, pp. xi-lxi.

${ }^{17}$ Diane P. Mines, Fierce Gods: inequality, ritual, and the politics of dignity in a South Indian village. Bloomington and Indianapolis: Indiana University Press, 2005.

${ }^{18}$ Murray Milner Jr, Status and Sacredness: a general theory of status relations and an analysis of Indian culture. New York: Oxford University Press, 1994, pp. 149-56; Srimati Basu
} 
at marriage by demands for dowry has been a very long-term historical process in India, pre-dating the coming of colonialism and reflecting the spread of the values of dharmic Hinduism both to new regions and social classes, and the status of hypergamous marriage as a route to upward social mobility within the framework of those values. ${ }^{19}$

These dimensions of gender hierarchy in Hindu marriage have given gender its key and continuing role in the maintenance of caste as hierarchy, helping shape what Tambiah has called 'the general Indian aspiration for maintaining and increasing status and honour through the institution of marriage' ${ }^{20}$ The setting for hypergamous marriage in securing the hierarchy of caste has worked most often at the fluid margins of large dominant landed castes, whose permeable boundaries could often absorb wife-givers from a range of smaller peasant and pastoralist communities, and where women marrying upwards reinforced other relationships of power and dependency. There is a rather different interplay between hypergamy and caste in the larger conglomerates of 'modern' ethnicized caste. In these settings, as Osella and others have argued, the erosion of subcaste barriers and the increasing use of socio-economic factors to measure status effectively opens up a caste-wide marriage market, in which hypergamous competition for desirable alliances has escalated, and with it, demands for dowry. ${ }^{21}$ While in some ways, therefore, ethnicization weakens caste as hierarchy, in others it strengthens the wider social framework which sustains caste. The development of wider caste identities gives fresh impetus to the place of hypergamous marriage as a key element in family strategy. This in turn reinforces the Hindu understanding that women are 'gifted' in marriage, so becoming the bearers of the relationship between their own and their husband's families, and the subordinate partners in the marriage relationship itself. These trends are reversed only at the level of India's

(ed.), Dowry and Inheritance: issues in contemporary Indian feminism. London: Zed Books, 2005 .

${ }^{19}$ For an example of the decline of bridewealth and inflation in dowry demands in eighteenth-century India, see Rosalind O'Hanlon, 'Disciplining the Brahman Household: the moral mission of empire in the eighteenth century Maratha state'. In Kumkum Roy (ed.), Looking Within, Looking Without: exploring households in the subcontinent through time. Essays in memory of Nandita Prasad Sahai. New Delhi: Primus Books, 2014, pp. $367-87$.

${ }^{20}$ S.J. Tambiah, 'From Varna to Caste through Mixed Unions'. In Jack Goody (ed.), The Character of Kinship. Cambridge: Cambridge University Press, 1973, p. 223.

${ }^{21}$ Filippo Osella and Caroline Osella, Social Mobility in Kerala: modernity and identity in conflict. London: Pluto Press, 2000, pp. 81-116. 
most affluent and educated middle classes. As Fuller and Narasimhan have noted in their study of Tamil elites, in these social settings it is the outward expression of gender equality, rather than the older 'Sanskritic' premium placed on asymmetric valuations of men's and women's independent social worth, that has come to be the stronger index of social status. ${ }^{22}$

\section{Regional difference in the transition to colonial caste}

All of these arguments point to significant elements of continuity, both direct and indirect, in caste as a form of privileged hierarchy in present-day India. Modern institutions of the state have certainly fostered new caste collectivities, which figure prominently in the public realms of politics and the law. Yet caste in these new guises continues to be sustained through complex patterns of personal, family, and religious life, many of them with much longer histories. It is certainly true that few scholars today posit a straightforward 'colonial invention' of caste. Yet many continue to assume that the links between caste and state power are a distinctive feature of the colonial state and the consequence of its legal and administrative interventions, which drew on Sanskrit texts and varna categories to order the caste status of its subjects. Similarly, many scholars continue to believe that 'nonBrahman' critiques of Brahman hegemony are very much the outcome of colonial rule. As I suggest below, however, neither the use of Brahman expertise in Hindu textual law, nor the idea of an oppressive Brahman minority bent on depriving others of a dignified ritual and religious life, originated—in Maharashtra at least—with the colonial state.

At one level, of course, it is the different longer term histories of caste across the subcontinent that is most striking. Historically, Kshatriya and Vaishya varna identities were less strongly represented in southern India. ${ }^{23}$ However, Sudra status embraced a wide range of meanings. Sudras could be kings, expressing their royal power not so much through the Vedic ritual associated with twice-born status, but rather in their role as first worshippers of the temple goddess. Likewise, dominant rural castes demonstrated their prestige in the

\footnotetext{
${ }^{22}$ Fuller and Narasimhan, Tamil Brahmans, pp. 123-52.

${ }^{23}$ Romila Thapar, Early India: from the origins to A.D. I 3 oo. Gurgaon: Penguin Books India, 2002, pp. 389-92.
} 
order of precedence in temple honours. ${ }^{24}$ Real social marginality lay not in Sudra status, but in the unfree labour of Paraiyans, although even here labour shortages and the flourishing maritime economies of pre-colonial South India offered many possibilities for social mobility. ${ }^{25}$ The coalitions of 'Right'- and 'Left'-hand castes in South India also cut across the conventional Sanskritic model of the varna order, with its emphasis on Vedic ritual as the distinctive marker of the dignities of the first three 'twice-born' varnas. ${ }^{26}$

In many parts of North India, on the other hand, a number of factors bolstered this model. Mughal imperial power created new idioms of centralized royal authority, which were in turn emulated by North India's most successful Rajput elites, who sought to transform Rajput identity from an open-ended status group into a closed royal lineage linked to India's ancient Kshatriya dynasties. ${ }^{27}$ The 'military labour market' from which North Indian states drew their armies meant that the prestige of martial identity continued nonetheless to be available to agrarian communities right across the Gangetic plains, and many of these articulated their own claims to Rajput and Kshatriya identity. North Indian traditions of military monasticism

${ }^{24}$ See Arjun Appadurai and Carol Breckenridge, 'The South Indian temple: authority, honor and redistribution' in Contributions to Indian Sociology (NS) 10,2 (1976): pp. 187-2 1 1; Nicholas Dirks, The Hollow Crown: ethnohistory of an Indian kingdom. Cambridge: Cambridge University Press, 1988; and Velcheru Narayana Rao, David Shulman and Sanjay Subrahmanyam, Symbols of Substance: court and state in Nayaka period Tamilnadu. Delhi: Oxford University Press, 1992; C.J. Fuller, The Camphor Flame: popular Hinduism and society in India. Princeton: Princeton University Press, 1992; David West Rudner, Caste and Capitalism in Colonial India: the Nattukottai Chettiars. Berkeley: University of California Press, 1994.

${ }^{25}$ Rupa Viswanath, The Pariah Problem: caste, religion and the social in modern India. New York: Columbia University Press, 2014; David Washbrook, 'Land and Labour in Late Eighteenth Century South India: the Golden Age of the pariah'. In Peter Robb (ed.), Dalit Movements and the Meaning of Labour in India. Delhi: Oxford University Press, 1993, pp. 66-86.

${ }^{26}$ Niels Brimnes, Constructing the Colonial Encounter: right and left hand castes in early colonial South India. London: Curzon Press, 1999, pp. 1-102.

${ }^{27}$ Norbert Peabody, Hindu Kingship and Polity in Pre-Colonial India. Cambridge: Cambridge University Press, 2003; Norman P. Ziegler, 'Rajput Loyalties During the Mughal Period'. In John F. Richards (ed.), Kingship and Authority in South Asia. New Delhi: Oxford University Press, pp. 242-84; Frances Taft, 'Honor and Alliance: reconsidering Mughal-Rajput marriages'. In Karine Schomer, Joan L. Erdman, Deryck Lodrick and Lloyd I. Rudolph (eds), The Idea of Rajasthan: explorations in regional identity. New Delhi: Manohar, 1994, Vol. 2, pp. 217-41; Ramya Sreenivasan, 'Kingship and authority reconsidered: Amber (Rajasthan), circa 1560-1615', Journal of the Economic and Social History of the Orient 57 (2014): pp. 549-86. 
reinforced these developments. ${ }^{28}$ The flourishing of Sanskrit literature and learning that took place all over India during the Mughal period itself contributed to the resilience of the conventional varna order, both by offering new defences against the levelling appeals of North Indian devotionalist movements, and by supplying new idioms of specifically Hindu kingship. ${ }^{29}$

As Jaffrelot has suggested, the colonial state accentuated the differences. The coming of European ideas in particular shaped the formation of new caste identities in the South and West. The Aryan racial theory of Orientalist scholars found a ready audience among those who were beginning to think of themselves as members of a broad lower caste collective. Out of these processes emerged a range of nonBrahman movements in the South and West, including Ambedkar's campaign in the Maratha regions and Dravidian movements in the South. New ethnicized caste identities went hand in hand with the emergence of caste associations, as British policies of reservation in education and local government further stimulated the emergence of a caste-based associational culture. In North India, on the other hand, these processes developed very much within the framework of Sanskritization. The Arya Samaj was able to garner very wide influence, drawing castes from Yadavas to Chamars. There were anti-caste movements in North India, but they tended to draw their ideas principally from the other-worldly forms of religious devotion. Consequently, North India's lower castes directed their energies principally to caste associations rather than to the formation of large non-Brahman groupings, or the assertion of rights on the basis of broad ethnic identities. The latter emerged only very recently, as successive governments expanded their schemes of caste reservation in the wake of the Mandal Commission. ${ }^{30}$

${ }^{28}$ Dirk Kolf, Naukar, Rajput and Sepoy: the ethnohistory of the military labour market of Hindustan, I450-I850. Cambridge: Cambridge University Press, 2002; William Pinch, Warrior Ascetics and Indian Empires. Cambridge: Cambridge University Press, 2006; Richard G. Fox, Kin, Clan, Raja and Rule: state-hinterland relations in preindustrial India. Berkeley and Los Angeles: University of California Press, 1971.

${ }^{29}$ Theodore Benke, 'The Śūdrācāraśiromaṇi of Krṣna Śeșa: a sixteenth century manual of dharma for Südras', PhD thesis, University of Pennsylvania, 2010; Monika Horstmann, Der Zusammenhalt der Welt; Religiöse Herschaftslegitimation und Religionspolitik Maharaja Savai Jaisings ( I 7oo-I 743). Wiesbaden: Harrassowitz, 2009.

${ }^{30}$ See in particular Christophe Jaffrelot, 'Sanskritisation vs. Ethnicisation in India: changing identities and caste politics before Mandal'. In Christophe Jaffrelot, Religion, Caste and Politics in India. New York: Columbia University Press, 201 1, pp. 449-58. 


\section{Vernacular critiques of caste in colonial India: a derivative discourse?}

This formulation is very much in line with the work of historians who have emphasized the colonial 'invention' of caste. As noted above, however, this perspective may be worth re-examining, in that it underestimates the degree of continuity into the colonial period, and portrays the vernacular critiques of caste developed in colonial India as essentially derivatives of colonial discourse. Yet many colonial intellectuals and activists were actually engaged in caste contests with much longer histories. They were deeply familiar with the complexities of these histories and with the issues at stake in them. Nor was the importance they ascribed to texts merely a second-hand reflection of Orientalist scholarship. They were aware that written texts of dharmasastra, caste puranas, the rulings of local judicial institutions, and local vernacular histories had been deeply consequential in past struggles, and in many cases continued to be so. Pre-colonial states as well as local caste communities took texts seriously as part of the apparatus of justice. The settings in which texts circulated, and the performance of the ritual dignities they confirmed or withheld, were often close to the muscular politics of the street and temple precinct. In some respects at least, the category of 'non-Brahman' was not just a catch-all absurdity of colonial caste discourse, but reflected deeper social histories and older contests, which continued to be significant well into the colonial period.

The history of caste in the Marathi-speaking regions of western India illustrates many of these characteristics. The states of the Deccan Sultanate inherited from the medieval Yadava kingdom a layer of conservative Brahman administrators in the countryside. Their scribal skills, religious prestige, and access to cash enabled them to amass extensive landed rights and rights over labour, which they enjoyed alongside the local Maratha gentry and military servants of the Deccan states. Caste identities in this setting were fluid. Their early pastoral origins gave Marathi-speaking peasant communities strong horizontal solidarities.

'Maratha' was an open-ended social category, associated with martial honours, and therefore open in principle to a wide range of socially aspirant rural communities who supplied military labour to local states during the campaigning season. ${ }^{31}$ Maratha domestic

\footnotetext{
${ }^{31}$ Stewart Gordon, The Marathas, I6oo- I 8 I 8 . Cambridge: Cambridge University Press, 1993, pp. 14-17.
} 
culture was also shaped by long traditions of service to the Sultanate states, creating Islamicized models for elite identity such as the seclusion of women and the practice of eating from a common dish. ${ }^{32}$ Other dimensions of Deccani culture also made for social cohesion. The region's great bhakti devotional traditions developed very much in the interplay between textual cultures, oral performance, and the routines of pilgrimage and worship associated with the tradition's major temples. As the Deccan Sultanate states pioneered the use of vernacular language for local justice and state administration, Marathi helped forge a new discursive community and new kinds of local familiarity with these states' documentary regimes. All of these processes strengthened the region's sense of a distinctive historical identity, sometimes encapsulated in the idea that there existed a 'dharma' of Maharashtra. ${ }^{33}$

At the same time, there were many strains. The emergence of the Deccan Sultanate states strengthened links with the Sufi devotional traditions of Islamic North India already forged under the Bahmanis, and opened the region more directly to the economies and cultures of the Indian ocean. Many heterodox sects flourished in this milieu. The social critique of bhakti poets, transmitted through hagiographies and collections of hymns as well as through oral tradition, gained a new and sharper edge. ${ }^{34}$ The literate skills of bhakti poets from humble backgrounds often formed a flashpoint of contest with conservative Brahman scholars. ${ }^{35}$ There were further frictions. Other newcomers to the Deccan, such as Kayastha scribal people from North

\footnotetext{
${ }^{32}$ Rosalind O'Hanlon, Caste, Conflict and Ideology: Mahatma Jotirao Phule and low caste protest in nineteenth century Western India. Cambridge: Cambridge University Press, ${ }_{19}^{8} 5$, pp. 18-20.

${ }^{33}$ Sumit Guha, 'Mārgī, Deśī and Yāvanī: high language and ethnic speech in Maharashtra'. In M. Naito, I. Shima and H. Kotani (eds), Mārga: ways of liberation, empowerment and social change in Maharashtra. Delhi: Manohar, 2008, pp. 129-46; Prachi Deshpande, Creative Pasts: historical memory and identity in western India. New York: Columbia University Press, 2007, pp. 19-39; Irina Glushkova, 'A Philological Approach to Regional Ideologies'. In Rajendra Vora and Anne Feldhaus (eds), Region, Culture and Politics in India. Delhi: Manohar, 2006, pp. 52-83.

${ }^{34}$ Christian Lee Novetzke, Religion and Public Memory: a cultural history of Saint Namdev in India. New York: Columbia University Press, 2011 ; John Keune, 'Eknath Remembered and Reformed: Bhakti, Brahmans and Untouchables in Marathi historiography', PhD thesis, Columbia University, 2011.

${ }^{35}$ Richard Eaton, A Social History of the Deccan, I30o-176I: eight Indian lives. Cambridge: Cambridge University Press, 2005, pp. 141-5o, 129-54; Gail Omvedt, 'The Bhakti Radicals and Untouchability'. In Manu Bhagavan and Anne Feldhaus (eds), Speaking Truth to Power: religion, caste and the subaltern question in India. New Delhi: Oxford University Press, 2008, pp. 11-29.
} 
India, found themselves in direct competition with Brahmans for administrative employment, sparking a fierce contest over Kayastha ritual entitlements. ${ }^{36}$ Brahman identity itself appeared less secure in this milieu, as expanding agrarian opportunities sharpened social divisions within Brahman. ${ }^{37}$ In turn, Brahman scholars mounted a vigorous defence of conventional caste and varna hierarchies.

\section{Vernacular sociologies of caste in early modern India}

One of the most successful of these was Gopinātha, from a Saivite scholar family living in the Nizam Shahi town of Paranda. He wrote his Sanskrit Jätiviveka, ('Discernment of Jātis') somewhere between the middle of the fourteenth and the later fifteenth centuries. He took as his model the caste classification sections of the ancient founding text of Hindu dharmasastra, the Manusmrti ${ }^{38}$ However, he modified it to reflect the local caste communities of his own region, their occupations, their ritual entitlements, their proper place in the hierarchy of varna and the Marathi as well as the Sanskrit names by which they were known. He presented it as a handy local compendium in a convenient abbreviated form: 'This book of Jātiviveka was expounded by the wise Gopisśvara in the world, extracting [the subject] from a great corpus of texts, including Manu and other smṛtis and śāstras.' Gopīnātha laid emphasis on the 'mixed' character of the world he observed. ${ }^{39}$

Here, only Brahmans and Sudras stood out as having maintained a purity of varna descent. Most of the jatis he described-which included every community and occupation he observed in the world around him-he listed as having come from fallen and hybrid parentages, often the result of transgressive pratiloma marriages. In other ways, too, Gopīnātha's treatise expressed his own very doctrinaire observations

\footnotetext{
${ }^{36}$ Rosalind O'Hanlon, 'The Social Worth of Scribes: Brahmans, Kayasthas and the social order in early modern India' in Indian Economic and Social History 47, 4 (2010): pp. 563-95.

${ }^{37}$ Rosalind O'Hanlon and Christopher Minkowski, 'What Makes People Who They Are? Pandit networks and the problem of livelihoods in early modern Western India' in Indian Economic and Social History 45, 3 (2008): pp. 381-416.

${ }^{38}$ Patrick Olivelle (ed.), The Law Code of Manu. Oxford: Oxford University Press, 2004 .

${ }^{39}$ Jātiviveka of Gopīnātha. British Library Sanskrit manuscript no. 1969, f. 2r. For a fuller discussion, see Rosalind O'Hanlon, Gergely Hidas and Cisaba Kiss, 'Discourses of Caste Over the Long Duree: Gopinātha and social classification in India, c. 14001900' in South Asian History and Culture 6, 1 (January 2015): pp. 102-29.
} 
on the world around him. He assigned Kayastha scribes and many communities of skilled craftsmen to the category of Sudra or even lower in rank. He was sharply aware of the challenge of bhakti, criticizing those he called 'Vaiṣnavas'. Citing the Viṣnupurāna, he asserted: "Those who abandon their karma and just recite "Kṛnna, Krṣna!" are sinners in the eyes of Hari. The birth of Hari is for the sake of Dharma. If you follow your varna, áśrama, and the prescribed conduct, you actually worship Viṣnu, the Highest Man.' He was sharply aware of the local presence of 'Turuska' rulers in the Deccan, rulers who supported themselves by their cruelties, and whose 'Mleccha language' good men should not learn or speak. ${ }^{40}$

What Gopinnātha offered, in effect, was a vernacular sociology of caste of a new kind. The Jätivivek a reflected his sense of the important role that Brahman scholars such as himself, armed with his handy compendium, should play in maintaining the proper orders of caste in the fallen era of the Kaliyuga, where people mixed and mingled promiscuously with one another, and Mleccha kings could not be counted on to protect dharma in the world. It was a consciously traditional treatment, reflecting on one level the views of a provincial Brahman scholar who found himself on the margins of the expansive and cosmopolitan new societies of the Deccan Sultanate states.

For all its uncompromising approach, however, many of Gopīnātha's contemporaries and successors appear to have found his treatise extremely useful. Communities of scholars and intellectuals-many of them of Maratha origin-flourished in sixteenth and seventeenth century Banaras. They came to exercise a subcontinent-wide role in matters of religious law, their authority enhanced by their prestigious place of meeting in the city's great temple to Siva. ${ }^{41}$ They drew on Gopinātha's social classifications, but modified them to suit their own local purposes. Perhaps more sharply aware of the competing popular appeal of North Indian bhakti, scholars such as Śeṣa Kṛ̣ṇa and Kamalākarabhatța, famous son of the Banaras Bhatța pandit dynasty, composed manuals such as the latter's Śndrakamalākara, which offered a comprehensive ritual life for virtuous Sudras. ${ }^{42}$

\footnotetext{
${ }^{40}$ O'Hanlon et al., 'Discourses of Caste', pp. 110-1 1.

${ }^{41}$ Rosalind O'Hanlon, 'Speaking from Siva's Temple: Banaras scholar households and the Brahman "ecumene" of Mughal India' in South Asian History and Culture 2, 2 (2012): pp. 253-77.

${ }^{42}$ Benke, 'The Sūdrācāraśiromaṇi of Kṛṣna Śșa'; Ananya Vajpeyi, 'Politics of Complicity, Poetics of Contempt: a history of the Sūdra in Maharashtra, 1650-1950', PhD thesis, University of Chicago, 2004.
} 
Kamalākarabhațta and his father, Rāmakrṣnabhațta, likewise took a more accommodating attitude to the question of whether, in the modern fallen era of the Kaliyuga, there could still be said to be intermediate varnas in the world, between Brahman and Sudra. From the vantage point of Banaras, it was difficult to overlook the power and status of North India's Kayastha, Khattri, and other scribal communities. Seventeenth-century Rajput courts, with their own emerging new discourse and rituals of kingship, were key sources of patronage for Sanskrit intellectuals. These concerns were reflected in the ways in which leading Banaras scholars adapted Gopinnātha's basic template of caste classification. They suggested that there were such varnas, and among them some Kayasthas of pure descent, as well as Kshatriya kings who had fallen away from their proper Vedic rituals but could still be purified and redeemed. Scholars from the Bhatta family, as well as others, composed Vedic consecration texts for Kshatriya kings from the early part of the seventeenth century. ${ }^{43}$

By this time, Gopīnātha's treatise had been reproduced, in part or in whole, in a further range of authoritiative texts of dharmasastra. The Brahman Dalāpatirāyā served Ahmad Nizam Shah (1490$1510)$ as chief minister and record keeper, and he commissioned a compendium of religious law-the Nrsimhaprasāda-which referred to 'the Jātiviveka' as one of its sources. The Brahman military officer, Pratāp Rai, served his successor, Burhan Nizam Shah (r. 1510-1533), and commissioned in his honour a much more substantial compendium of religious law-the Paraśurāmapratāpawhich incorporated almost the whole of the Jätiviveka in its pages. Written in the late sixteenth century, and part caste purana, part sectarian polemic, the Śatapraśnakalpalatā or 'Wishing Tree of 100 Questions' of Mādhava, offered both 'condensed' and 'expanded' versions of Gopinātha's text. Sometime in the later seventeenth century, one Rāmacandra Bāpat wrote a Bṛhajjātiviveka ('Expanded Jātiviveka'), which reworked many of Gopīnātha's classifications. His text also circulated in Banaras as part of another genre entirely, that of the Sanskrit genre of Vāstuśāstra, reflecting the importance of

\footnotetext{
${ }^{43}$ Sheldon Pollock, The Ends of Man at the End of Premodernity. Amsterdam: Royal Netherlands Academy of Arts and Sciences, 2004, pp. 63-78; Madhav Deshpande, 'Kșatriyas in the Kali Age? Gāgābhațta and His Opponents' in Indo-Iranian Journal 53, 2 (2010): pp. 96-100, 110-16; O'Hanlon, 'The Social Worth of Scribes', pp. 571-73.
} 
occupation in the construction of different wards and quarters in the early modern city. ${ }^{44}$

It was against this background of disagreement about what orders of varna could be said to exist in the modern age of the Kaliyuga that Gāgābhațta, nephew of Kamalākarabhațta and himself equally persuaded of the legitimate existence of Kshatriyas, came to the Maratha court of Raigad in 1673 for the consecration of the Maratha warrior ruler, Sivaji. This now famous occasion entailed many days of complex ritual, in which the Bhosle family's early lapses from Vedic observance were repaired, and the way opened for Sivaji's 'rebirth' as a royal Kshatriya and a dharmic king. ${ }^{45}$ During Gāgābhaț̣a's visit, he also drew on Gopīnātha's text to compose a ritual manual for Kayasthas at the court. It was a disappointment to them, because it prescribed only a lesser form of quasi-Vedic ritual for them, which left their varna status open to doubt. The issues continued to provoke sharp debate early in the following century, particularly with the rise of Rajput demands for their own new forms of royal and Vedic ritual. The Rajput ruler, Savai Jai Singh of Jaipur (1688-1743), hosted a debate at his court specifically to determine the question of whether lapsed Kshatriyas could recover their Vedic ritual dignities by suitable penances. Most local pandits followed the older position of Gāgābhaț̣a and agreed that they could. But the conservative position still found its supporters, notably in Gāgābhațta's junior contemporary, the leading grammarian of Banaras, Nāgeśabhațta, who refused to appear at the debate, but set out his objections to any presence of pure Kshatriyas in the Kaliyuga in a lengthy treatise, the Vrätyatāprāyaścittanirnaya ('Judgement of penances by those who have fallen from caste'). ${ }^{46}$

\section{Caste and elite violence in the Maratha state}

These arguments about the structure of varna took on new dimensions in the eighteenth-century Maratha state. Many developments reinforced the older Sultanate-inflected model of elite Maratha status. North Indian cultural influences were strengthened with the rise of new Maratha lordly families under the leadership of the peshwas.

\footnotetext{
${ }^{44}$ For circulation of the Jätiviveka, see O'Hanlon et al., 'Discourses of Caste', pp. $112-14$.

${ }^{45}$ V.S. Bendrey, Coronation of Shivaji the Great. Bombay: P.P.H. Bookstall, 1960.

${ }^{46}$ Deshpande, 'Kṣatriyas in the Kali Age?', pp. 110-12.
} 
The new Maratha families based themselves in their military estates in North and central India, and their heterogeneous armies came to include many North Indian troopers. By the 1730 , these Islamicate models were affecting even the women of elite Maratha Brahman families. Radhabai, matriarch of the peshwa's own family, found herself asked to don purdah for the marriage of her daughter, Anubai, to the Brahman, Sardar Venkatrao Ghorpade of Ichchalkaranji. ${ }^{47}$

In other respects, however, the older arguments about Vedic ritual and Kshatriya status acquired new salience in the eighteenth-century Maratha state, particularly as power passed from the Satara court of the Maratha ruler, Shahu I (1688-1749), into the hands of his Chitpavan Brahman peshwa ministers in Pune. As Pune city expanded and its ranks of state servants, skilled artisans, and gentry flourished with the inward flow of wealth from the new Maratha domains in central and northern India, the peshwas sought to enhance their authority and their powers of social regulation by emphasizing their role as guardians of dharmic propriety. They imposed tighter social disabilities on those judged to be Sudras, explicitly denying them entry to important temples and in some cases issuing detailed orders for their permitted social and bodily comportment. ${ }^{48}$ The question of Maratha rights to Vedic ritual continued to have some political traction. The peshwa, Nanasaheb, ensured that the descendants of Sivaji at the Satara court had their life-stage rituals performed with puranic, rather than Vedic, ritual. ${ }^{49}$ In her drive to recruit political support after Shahu's death, the veteran Maratha queen, Tarabai Shinde of Kolhapur, raised the royal Kshatriya status of Sivaji and his descendants-Maratha kings now deprived of their authority by upstart Brahmans. ${ }^{50}$ Older established Brahman subcastes in turn resented this new Chitpavan role as arbiters of religious rectitude, particularly when it extended, as it sometimes did, into local disputes between different Brahman communities over priestly rights.

\footnotetext{
${ }^{47}$ V.V. Khare (ed.), Ichalkaranj̄̄ Sansthānca Itihāsa vā Ichalkaranjī Daftarātūl nivadak patre va yādī. Miraj, 1913, p. 28.

${ }^{48}$ Sudha Desai, Social Life in Maharashtra Under the Peshwas. Bombay: Popular Prakashan, 1980, pp. 28-40; N.K. Wagle, 'The government, the jāti and the individual: rights, discipline and control in the Pune Kotwal papers, 1766-94' in Contributions to Indian Sociology 34, 3 (200o): pp. 321-6o; Hiroshi Fukazawa, The Medieval Deccan: peasants, social systems and states, sixteenth to eighteenth centuries. Delhi: Oxford University Press, 1991, pp. 91-113.

${ }^{49}$ Dhananjay Keer, Rājrși Ś āhū Chhatrapatī. Bombay: Popular Prakashan, 1979, p. 86, and M.G. Dongare (ed.), Siddhāntavijaya. Kolhapur: Mission Press, 1905.

${ }^{50}$ Eaton, $A$ Social History of the Deccan, pp. 196-97.
} 
It was in these factional settings and struggles for political advantage that the politics of caste took on new significance. One important arena lay at the Satara court. Following a long-established principle of Maratha statecraft, the Maratha raja, Shahu, maintained a powerful constituency of Kayastha administrators at court, to offset the influence of Brahman state officials and to ensure that neither achieved a dominating influence. ${ }^{51}$ As the raja's health worsened during the late 1740 s, leaders within the two communities manoeuvred more intently for advantage. In this setting, it became a key Brahman tactic to attack the varna status of the Kayasthas, and have them declared to be menial Sudras, without rights to the dignity of Vedic ritual and, by implication, unfit to be the confidential servants and advisers of the king. By early 1749 , this produced a crisis. A party of Kayasthas journeyed to Banaras and then on to Prayag, where they persuaded local Brahman priests to perform the Atirudra ritual for them, a great Vedic sacrifice that would publicly confirm their twiceborn status. To keep the ritual from being disrupted, the party also employed a posse of Muslim foot-soldiers belonging to the Muslim governor of Prayag around the fire-pit. But the Brahman leaders in Pune and Satara had their own allies among the long-established Maratha scholar families in North India. As soon as news of the rite leaked out, they rallied these supporters, and the priests who had agreed to perform the Kayastha ritual were declared to have transgressed so gravely as to be banished from the caste. ${ }^{52}$

Under these pressures, the raja and his advisers convened a great gathering of pandits from different parts of the Deccan to determine the real identity of Satara's Kayasthas. Tension in the city grew as some 10,000 Brahmans gathered in the streets around the court to await the verdict. Among the textual authorities produced at the debate were Gopīnātha's Jātiviveka and the manual that Gāgābhațta had written for the Kayasthas, both conveying the same vision of a world containing no pure varnas between Brahman and Sudra. On the strength of these and other authorities, the pandit assembly found against the Kayasthas, as 'the offspring of mere Sudras'. The pandits

\footnotetext{
${ }^{51}$ Surendranath Sen, Extracts and Documents Relating to Maratha History. Vol. I, Siva Chhatrapati. Calcutta: University of Calcutta, 1920, pp. 29-30.

${ }^{52}$ Viśṇu Māhādev Āṭhalye (ed.), Āthalye Gharanyāāā Itihās. Pune: Viśṇu Māhādev Āthalye, pp. 61-66. A more detailed account is in 'Parabhüjātinirnaya', unpublished Sanskrit and Marathi mss, no. $5^{67}$ of $1883-4$, Bhandarkar Oriental Research Institute, Pune.
} 
drove home the point in relation to the Maratha ruler, Sivaji himself, invested as Kshatriya by the priest, Gāgābhațta, some 8o years earlier: 'The late Gāgābhațta, learned in the Vedas and Sāstras, performed the King's sacred thread ceremony as a Kshatriyas, with the Gāyatri mantra. That rite did not succeed in its aims. The lineages of both died out. This is the consequence of bad behaviour. ${ }^{53}$ Shahu's death in November 1749 and the transfer of political authority to the peshwa's court in Pune represented a further blow to the Kayastha position. Nonetheless, they remained powerful rivals, and the dispute impelled at least one of their leaders, Sakharam Bapu Gupte, to conspire in the murder of the peshwa, Narayanrao, in 1773 . Their varna status, with all its symbolism, continued to be the focus of struggle. Further assaults followed in 1789-90, when many dozens of Kayastha leaders were forcibly confined to their houses until they agreed to an order accepting a long list of ritual disabilities, which was then sent out to state officials to enforce. ${ }^{54}$ By the end of the century, many Kayasthas left to serve as administrators in Maratha states elsewhere in India.

Varna standing and other forms of ritual entitlement continued to be the touchstones in other elite political and factional struggles. Ritual standing, social dignity, and material interest blended together in these struggles. Some communities of Sonar goldsmiths had prospered very substantially under the peshwas. They were aided by the flourishing of Pune as a financial centre and the proliferation of state-licensed private mints, often in the hands of Sonars. ${ }^{55}$ Elite Sonars sought the dignity of Vedic ritual and twice-born status, claiming to be lineal descendants of Viśvākarma the divine artificer, entitled as 'minor Brahmanas' to Vedic ritual, and to employ priests of their own caste. Their transgressions attracted severe corporal punishments. ${ }^{56}$ The Bombay government was drawn in to prevent the Sonars from using the dignified 'Namaskār' mode of salutation

${ }^{53}$ V.S. Bendrey, Mahārā retihāsāci Sādhane. Mumbai: Mumbai Marathi Grantha Sangrahalaya, 1966, Vol. II, pp. 491-95. For this episode, see also Deshpande, 'Kșatriyas in the Kali Age?', pp. 103-04.

${ }^{54}$ Narendra Wagle, 'The Cāndrasenīya Kāyastha Prabhus and the Brahmans: ritual, law and politics in Pune: 1789-80'. In Gunther-Dietz Sontheimer and Paramesvara Arthal (eds), Indology and Law: studies in honour of J. Duncan M. Derrett. Wiesbaden: Franz Steiner Verlag, 1982, pp. 303-28; Ganesh Chimnaji Vad, Selections from the Satara Raja's and the Peshwa's Diaries. Vol. 8, no. 3: Selections from the Diaries of Sawai Madhavrao Peshwa. Pune: Deccan Vernacular Translation Society, 191 1, pp. 287-92.

${ }^{55}$ D.C. Sircar, Studies in Indian Coins. Delhi: Motilal Banarsidas, 1968, pp. 274-75.

${ }^{56}$ Desai, 'Social Life in Maharashtra', p. 39; V.K. Rajwade (ed.), Marathyancya Itihāsāci Sädhane, Pune: Chitrasala Press, 1918 , Vol. XXIV, nos 13, 22, 23. 
appropriate to the twice-born. A 28 July 1779 Resolution recorded that 'the exercise of such ceremony by the Goldsmiths is a great breach of the Gentoo Religion, and repeated complaints have been made to us by the Brahmins and the Peishwa also several times having written to the President requesting [that] the use of the Namascar might be prohibited to the Goldsmiths'. The head of the community was instructed to desist accordingly, the resolution went on, 'as a compliment to the Peishwa'. ${ }^{57}$ Contests continued among smaller regional Brahman communities such as the Shenvis and the White Yajurvedis, very often when more dominant Brahmans challenged their status as 'pure' Brahmans and, with it, their entitlement to the livings attached to priestly work. These conflicts sometimes degenerated into violence, as when a pair of Chitpavan Brahmans broke into a White Yajurvedi temple and forcibly removed the deities which, they said, the Yajurvedis had no right to serve. ${ }^{58}$

Here, then, older conflicts over the nature of the varna order received fresh impetus as the peshwa governments sought to extend the central reach of the state into matters of caste regulation, and to weaken other powerful groups in the state by depriving them of the public dignities of Vedic ritual. Local caste leaders also exploited the nexus between caste and politics by using their connections in Pune to pursue local ambitions and grievances.

Texts, both in the form of sastric treatises such as that of Gopinnātha, and the written judgements of pandit assemblies, mattered deeply to the outcome of these struggles. They informed judgements of the state, which state officials as well as community leaders frequently enforced, and they were taken seriously as one of the indices of a community's social rights and standing. So too, however, did the ability to field muscular supporters on the street, to protect a disputed ritual, to focus the mind of a pandit assembly, or to manhandle deities out of a contested temple. Social dignity, political leverage, and material livelihoods were all at issue in these conflicts over the Vedic dignities allowed to the twice-born, and the fundamental question as to whether any but Brahmans and Sudras remained in the fallen era of the Kaliyuga.

\footnotetext{
${ }^{57}$ Resolution of the Government of Bombay, 23 July 1779.

${ }^{58}$ R.B. Gunjikar, Sarasvatī Mandala. Bombay: Nirnayasagar Press, 1884, Appendix 2, no. 2; Rosalind O'Hanlon, 'Contested Conjunctures: Brahman communities and "early modernity" in India' in American Historical June (2013): pp. 781-86.
} 


\section{Brahmans and Sudras: Gopinātha in the colonial archive}

The social world that the colonial state inherited in western India was not, therefore, simply a geographical region in which 'intermediate' castes were poorly represented. Rather, the question itself was a bitterly contested one, in which the ascent of Brahman power during the eighteenth century had enabled the orthodox advocates of a society polarized between Brahmans and Sudras to entrench their views. Although the move to the ethnicization of caste identities was to come later in the nineteenth century, the Brahman/non-Brahman divide itself lay already implicit in those contests. When, therefore, Marathas, Kayasthas, Sonars, and other elite 'non-Brahmans' turned to social campaigning during the 1820 s and 1830 os, the issue of Vedic dignities continued to lie at the heart of their programmes. Pandit assemblies were convened to debate what had now become the 'Vedokta' issue in Satara, Bombay, Pune, and Baroda. The Bombay government was drawn in: in April 1824, the Bombay Sonars, led by the influential banker, Jagannath Shankarseth, petitioned the Bombay government for help in securing their rights. ${ }^{59}$ The campaigns culminated in a major debate about Vedic rights sponsored at his court by the Satara raja, Pratapsinh (1793-1847). Again, sastric texts and religious judgements figured prominently in the proceedings. The Kayastha scholar, Ābā Sāheb Pārasnīs, led the case for the raja, compiling a large digest of relevant documents, the Siddhāntavijaya, which contained many of the texts of dharmasastra and legal judgements from the eighteenth century and earlier. ${ }^{60}$ Led by Nilakaṇta Śāstri Thațte, the Brahman party likewise drew for its arguments on its own deep intellectual roots. Thatte belonged directly to the scholarly lineage of the Banaras grammarian, Nāgeśabhațta, who, as we have seen, had championed the conservative position against the arguments of Savai Jai Singh of Jaipur in the early decades of the eighteenth century. ${ }^{61}$

\footnotetext{
${ }^{59}$ For the elite non-Brahman social campaigns of the 1820 s and 1830 , see Narendra Wagle, 'A Dispute between the Pancal Devajna Sonars and the Brahmins of Pune Regarding Social Rank and Ritual Privileges: a case-study of the British administration of jati laws in Maharashtra, 1822-1825'. In N.K. Wagle (ed.), Images of Maharashtra. London: Curzon Press, 1980, pp. 129-59; Narendra Wagle, 'Ritual and Change in Early Nineteenth Century Society in Maharashtra: Vedokta disputes in Baroda, Pune and Satara, 1824-1838'. In Milton Israel and N.K. Wagle (eds), Religion and Society in Maharashtra. Toronto: University of Toronto, 1987, pp. 145-81.

${ }^{60}$ Dongare, Siddhãntavijaya, p. 6.

${ }^{61}$ Deshpande, 'Kṣatriyas in the Kaliyuga?', pp. 110-13.
} 
Again, the debates took place in an atmosphere of barely suppressed violence, the chamber guarded by soldiers, and the raja himself armed.

There were long textual continuities in other ways too. To the consternation of the Kayasthas, Sonars, and others, the Jätiviveka was beginning to appear in the colonial apparatus of government as a book of authority. H.H. Wilson, then secretary to the Committee of Public Instruction, and soon to emerge as a distinguished Indologist in the East India Company service, examined the Sonars' entitlements in 1824. He had before him a range of texts of religious law, including the Jätiviveka and the later Ś̈́drakamaläkara, through which parts of the Jätiviveka had circulated during the seventeenth century. Handwritten Sanskrit quotations from these and other texts appear in the margins of his work, revealing active guidance from local Brahman scholars anxious to ensure that Wilson came to the right conclusions. ${ }^{62}$ Arthur Steele, charged in the early 1820 s with compiling an accurate account of the 'law and custom' of Hindu communities in the Company's new Deccan provinces for use in the Bombay courts, cited 'the 'Jatiwiwek' and other texts particularly recommended for their accurate account of caste classification. ${ }^{63}$ Dissemination of the Jativiveka may actually have increased in these early years of the Company's state. James Molesworth first published his English-Marathi dictionary in 1831, ably assisted by a team of learned pandits. The entry for Kayasthas simply recorded that they were a community of writers. ${ }^{64}$ By the time Molesworth came to publish the second edition in Bombay in 1857, however, the entry for Kayasthas was much fuller. 'See the book Jätiviveka,' the entry read, and quoted at some length from the Jativiveka's account of the degraded origins of Kayasthas in transgressive marriages and degraded forms of sexual contact. ${ }^{65}$

\footnotetext{
62 'Remarks of Mr H.H. Wilson, Secretary to the committee of Public Instruction, communicated to the officiating Chief Judge of the Court of Sudder Dewanay Adawlut, in December 1924.' Bombay Judicial Department, 1825, Vol. 7/87, pp. 21-57, Maharashtra State Archives, Mumbai.

${ }^{63}$ Arthur Steele, A Summary of the Law and Custom of Hindoo Castes within the Dekhun Provinces Subject to the Presidency of Bombay. Bombay: Courier Press, 1827, pp. xi-xii.

${ }^{64}$ J.T. Molesworth, Dictionary, Murat, hee and and English. Bombay, 1831 , p. 148.

${ }^{65}$ J.T. Molesworth, A Dictionary, Maráthí and English. Bombay: Education Society's Press, 1857 , p. $15^{8}$.
} 
'To refute my opponents with their own weapons': Tukārām Tàtyā Paḍal and the conservative tradition of the Jätiviveka

If continuities marked these elite concerns-and, indeed, the process of knowledge- gathering itself during these first years of the East India Company state-what of those early colonial intellectuals who went on to a more radical intervention in the long-standing debate about varna hierarchies? The dominant figure in the non-Brahman politics of nineteenth-century western India is that of Jotirao Phule (1827189o). As is well known, Phule founded western India's first nonBrahman political organization, the Satyashodhak Samaj, in 1873 . During the 1870 s, he also developed what was to become a key plank in non-Brahman ideologies in many parts of India. This was the theory that Brahmans were the descendants of the early Aryan invaders of India, and caste the instrument of their subsequent social domination of India's indigenous peoples, its bahujan samāj or 'community of the majority of people', which included Kshatriya warriors denied their true identities as well as Sudra toilers and labourers. ${ }^{66}$ This attempt to forge a broad jati collectivity represented the moment of 'ethnicization' in western India. However, its vision of a society polarized between Brahmans and others, and its assimilation of older concerns with ritual dignities to a new identity in which social worth lay with those who protected the land and those who laboured to make it fruitful, were very much a reflection of the older debates described above.

Yet the earliest work of what might be called 'non-Brahman' critique in the Maratha country, and an even more direct link with the earlier debates around the Jativiveka, came from the pen of a young Bombay man, Tukārām Tātyā Pạ̣val (1838-1898). Paḍval came from a successful Bhandari family in Bombay, and was to go on to work closely with other moderately prosperous merchant and small business people in the movement for municipal reform in the $1870 \mathrm{os} .{ }^{67}$ With the help of Phule, who was named as publisher of the book, Padval published his Jätibheda Vivekasāra ('Essence of the discernment of distinctions between jatis') in $\mathbf{1 8 6 1}$, and republished it in $186_{5}$ in a more extended edition. ${ }^{68}$ While Padval did not mention the Jätiviveka itself, the very

\footnotetext{
${ }^{66}$ For a summary, see Rao, The Caste Question, pp. 39-57.

${ }^{67}$ Christine Dobbin, Urban Leadership in Western India. Politics and communities in Bombay city. Oxford: Oxford University Press, 1972, pp. 137 and 253.

${ }^{68}$ Jātibheda Vivekasāra. Bombay: Ganpat Krishnaji's Press, 1 865. As author, Padval identified himself simply as 'A Hindu'. References here are to the 1865 edition.
} 
title of his work identified it consciously as a voice of opposition within the larger genre. Moreover, his central polemical tactic was to take the Jativiveka's vision of a social world irredeemably mixed, and turn it against the long tradition of argumentation as it had developed historically and into his own time. The whole notion of purity of descent anywhere in Hindu society was a fiction. All communities, from Brahmans to the humblest of Untouchables, were in reality irretrievably mixed in their origins and in the motley professions and modes of life they pursued. What gave Padval's work additional force was his detailed knowledge of the history of conflict over caste in the Maratha country, and the key role of ritual and of texts in that history. His was another astute and historically aware vernacular sociology, but this time one that aimed at undoing the whole regional discourse of varna and caste, using its own very instruments. As he explained in his introduction, 'I have thought it was a good stratagem to refute my opponents with their own weapons. ${ }^{\text {'69 }}$

Paḍval's analysis proceeded in three broad stages. India's caste system, he argued, had at first been a practical division of labour in which people were able to move flexibly according to their talents and aptitudes. It had hardened into a rigid hierarchy from the time of the late classical philosopher monk, Shankaracharya, who had destroyed the influence of India's Buddhist communities, entrenched the varna order as the basis of all religion, and represented Brahmans at its head as gods on earth, fit to be worshipped no matter what their conduct. After extensive quotations from the Manusmrti and other epic and puranic texts, he moved on to look at the real history of caste identities and relations in the Maratha country. He quoted extensively from the insulting puranic texts through which Maharashtra's Brahman communities had historically pursued their mutual rivalries, in which each described menial and transgressive origins for their opponents. ${ }^{70}$ The Maratha community considered themselves Kshatriyas. But this dated only to the time when the Marathas had acquired an empire in the time of Sivaji. 'At that time, Gāgābhaț̣a wrote the book that determined him to be a Kshatriya. He invested him with the sacred thread using the Gāyatrī mantra, thus establishing his entitlement to Vedic rituals. It is from that time that Marathas have worn the sacred thread. But once Brahmans saw that their empire was gone, they reverted to using puranic ritual only for them.' Not only that, but the

\footnotetext{
${ }^{69}$ Jatibheda Vivekasāra, p. 2 of the introduction to the second edition.

${ }^{70}$ Ibid., pp. 40-45.
} 
Marathas had adopted many Muslim social customs, such as the veiling of women, from their overlords in those days. ${ }^{71}$ Likewise, the claims of Kayasthas, Sonars, and many other castes to be pure Kshatriyas were simply impossible to prove, and belied by the visible evidence of social mixing and merging of livelihoods and modes of life. In support of his contention that all castes, not just those between Brahman and Sudra, were mixed in the modern era, Padval actually cited verses from the Jätiviveka, but as these in turn had been reproduced in the work on Sudra ritual life of the Banaras pandit, Kamalākarabhațta, referred to above. $^{72}$

Padval followed this upending of the inherited discourse of caste in western India with a remarkably clear-eyed critique of the adverse sociological consequences of caste in his own times, arranged under a series of headings. Intellectually, caste limited educational opportunities for all but a few, leaving the minds of the majority cramped 'like the bound feet of Chinese girls'. Brahmans who did have access to education closed their minds to the knowledge of science, such that many would tell you 'that the earth was as flat as the leaf of a Pipal tree, and rested on the head of the great snake, Shesha'. Many felt they could make a good living with little effort, and so themselves were in many cases poorly educated, limiting themselves to rudimentary clerical knowledge. ${ }^{73}$ In ethical terms, pride of caste made people immune to the sufferings of the poor and the starving. It led to crimes against women, such as the killing of girl babies, practised by Rajputs, and the custom of Kulin Brahman polygamy in Bengal. Manu and other ancient texts of religious law laid down savage punishments for the lower castes and the greatest leniency for high caste transgressors, such that the latter often felt that they were above the law. ${ }^{74}$ India's trades and craftsmen possessed only poor levels of skill, in many cases because caste limited mobility and forced people simply to practise their hereditary family professions. Caste also prevented Hindus from travelling abroad, trading, learning, and mixing comfortably with outsiders. ${ }^{75}$ The political disadvantages of caste were equally severe. India's warrior classes of Kshatriyas and

${ }^{71}$ Ibid., pp. 43-44.

${ }^{72}$ Ibid., pp. 47-49. For the transfer of this material from Gopīnātha's Jātiviveka to Kamalākarabhaț̣a's Súdrakamalākara, see O’Hanlon et al., 'Discourses of Caste', p. 115 .

\footnotetext{
${ }^{73}$ Ibid., pp. 61-63.

${ }^{74}$ Ibid., pp. $63-8$ o.

${ }^{75}$ Ibid., pp. 80-91.
} 
Rajputs were too divided by caste to resist the waves of conquerors from the northwest who followed Mahmud of Ghazni. In more recent times, caste had prevented Brahmans and Marathas from joining forces to resist the forces of the English. ${ }^{76}$ Padval concluded this part of his treatise by listing the spiritual disadvantages of caste, quoting extensively from Hindu devotionalist, Buddhist, and Jain writers from different parts of India who had themselves protested against its false values. $^{77}$

In the last part of his text, Padval returned to the specific history of caste struggles in western India. He assembled a range of eighteenth-century judicial documents through which various castes had contested their identities. There was a Banaras pandit assembly's judgement from 1788, dismissing the claims of the Bombay Palashe community to Brahman status and priestly livelihoods. There were two judgements from the Shankaracharya of Sringeri matha in Karnataka, one of the South India's great authorities in matters of Hindu religious law, about the rights of Palashes to work as priests to Kayasthas, and the claims of Shenvi communities in Bombay to full Brahman status. There was a copy of the 1779 ruling from the governor of Bombay referred to above, in the matter of disputed Sonar claims. He included a very interesting order dating from 1743 , from the Maratha peshwa to the Brahman religious leaders of the town of Cheul outside Bombay. The order described how many eminent Brahman pandits had been assembled in Pune to rule on the claims of the Kayastha community of Pattane Prabhus, who had been observed commissioning priests to carry out Vedic rituals to which they were not entitled. The assembly had judged them to be mere Sudras. The peshwa's letter ordered that in future the community were to be allowed puranic ritual only for their domestic ceremonies, and were to permit widows of the caste to remarry in conformity with the dharma proper to Sudras. ${ }^{78}$ To these evidences of the hybrid identities of Brahman and Kayastha communities, Padval added information about India's Rajputs and lordly Maratha families drawn from British sources. James Tod, the great authority on Rajput history, had traced Turkish origins in many Rajput families. The historian, Grant Duff, had described the humble

\footnotetext{
${ }^{76}$ Ibid., pp. 91-98.

${ }^{77}$ Ibid., pp. 98-137.

${ }^{78}$ Ibid., pp. $137-58$.
} 
origins of Sivaji's own family. ${ }^{79}$ The old Maratha clans who claimed purity of Rajput descent were in fact socially mixed, as was clear from their recent intermarriages with the lowly families of Shinde and Holkar, 'so it is clear how much purity remains amongst the Maratha people' ${ }^{80}$ Padval concluded his text with a lengthy classification, very much in the style of the Jativiveka, of 'the jatis which are found in the country of Maharashtra'. As Gopīnātha had done, Paḍval included a brief description of each community's place of origin, their occupation, mode of life, and, in some cases, their claimed or attributed varna identity. $^{81}$

The first edition of Padval's book caused quite a stir in Bombay, with reviews in the Marathi and the English language press, and appeared in a second, expanded edition in 1865. The book was promoted in Pune by the missionary, Adam White, part of the Pune missionary circle that included Jotirao Phule. ${ }^{82}$ It made a strong impression on the Marathi writer and social observer, Govind Nārāyan, who noted it in his Mumbaice Varnan ('Description of Bombay'), published in 1863 . Describing the intense social competitiveness of caste communities in the city, and caste fissions occasioned by minute disagreements over ritual observance, Nārāyan reported that, 'In 1861, an enquiring gentleman prepared and published a book called the Jatibhed Viveksaar for the welfare of the people.' The book 'contains numerous examples from the Vedanta and other books regarding the futility of caste. People should certainly read this book. ${ }^{93}$

Padval therefore displayed a remarkably detailed knowledge of caste struggles dating back two centuries and more, and a sharp awareness of the role that texts of many different kinds could play in those struggles, from seventeenth-century texts of dharmasastra, to the judgements of pandit assemblies in Pune and Banaras, to orders of the peshwa government in Pune or the government of Bombay. What was also striking in his position was that it contained no suggestion of

\footnotetext{
${ }^{79}$ Padval's references here are to James Tod, Annals and Antiquities of Rajasthan. London: Smith Elder, 1832, and James Grant Duff, A History of the Mahrattas. London: Longmans, Rees, Orme, Brown, and Green, 1826.

${ }^{80}$ Jātibheda Vivekasāra, p. 153 .

${ }^{81}$ Ibid., pp. ${ }^{1} 5^{8-70}$.

${ }^{82}$ Ibid., p. 2 of Introduction to the second edition. The Pune missionary circle is described in Murrary Mitchell, In Western India: recollections of my early missionary life. Edinburgh: David Douglas, 1899, pp. 314-16.

${ }^{83}$ Murali Ranganathan (ed.), Govind Narayan's Mumbai. An urban biography from 1823. London: Anthem Press, 2008, pp. 303-04.
} 
any new kind of ethnicized caste collective. He engaged closely with Maharashtra's long-established tradition of debate as to whether there were any intermediate castes in the modern world. However, he used that tradition not to suggest a new combination, but rather to attack and undo all social unities that were built on the basis of caste, itself a corrupting principle of social life. In this, of course, his approach differed from that of Phule, who shortly after was helping Padval with his treatise and beginning to develop his thesis of the essential unity of all non-Brahman castes against their Brahman oppressors. In this, Padval stands as an important and little-recognized intellectual predecessor of Ambedkar, who began to develop his own assault on caste some 6o years later in the 1920 .

Throughout these years, Gopinātha's Jātiviveka and the tradition it had come to represent remained at the centre of argumentation about caste, shaping 'colonial knowledge' and continuing to draw attention from communities who found themselves classified in its terms. It entered the literature of colonial anthropology through the work of the missionary, John Wilson, the first volume of whose Indian Caste was published in Bombay in 1857 . It described 'the Jati-Viveka, the Brahajjati-Viveka, the Madhava-Kalpalita, and the Parashurama Pratapa' as 'works of authority among the Maratha Brahmans'. ${ }^{84}$ In his 1877 account of his community's history and customs, the Bombay Kayastha, Shamrao Moroji Nayak, included the Jätiviveka, the Paraśurāmapratāpa, the Śatapraśnakalpalatā, and the Bṛhajjātiviveka within a list of Sanskrit works that gave no proper account of his community of Pattane Prabhus, 'for the reason that they are written by the Shastris and not by the sages of ancient times'. ${ }^{85}$ In 1880 the essayist and social reformer, V.N. Mandlik, cited the 'Jativiveka, large and small' in his list of authoritative works of dharmasastra in the Maratha country. ${ }^{86}$ These pressures continued to provoke Kayasthas and others in the new context of competitive history writing that gathered pace from the 1870 s. $^{87}$ As late as 1919 , the writer and non-Brahman activist, K.T. Gupte, inveighed against the Jätiviveka, as a text that 'determined everyone other than Brahmans to be inferior

${ }^{84}$ John Wilson, Indian Caste. Bombay: Times of India Office, 1877 , Vol. 1, p. 64. For the earlier publication of the work, see George Smith, The Life of John Wilson. London: J. Murray, 1878 , p. 482 .

${ }^{85}$ Shamrao Moroji Nayak, A History of the Pattana Prabhus. Bombay: Family Printing Press, 1877 , p. 30 .

${ }^{86}$ V.N. Mandlik, The Vyavahāra Mayūkha. Bombay: Education Society's Press, p. lx.

${ }^{87}$ Prachi Deshpande, Creative Pasts, pp. $126-76$. 
and Sudras. In its opinion, goldsmiths, carpenters, weavers, gardeners, braziers and coppersmiths are all inferior and Sudras. ${ }^{98}$

\section{Afterword}

By this time, of course, caste was firmly established as a dominant force in the public spheres of law, politics, and education. Caste associations everywhere sought to extend their memberships, and looked to the colonial state as well as their own histories for affirmation of their identity. Non-Brahmans in western and southern India challenged assumptions that they could be easily assimilated into Congressled nationalism, and early Dalit leaders, including Ambedkar, were beginning to demand organizations and a voice of their own. As is well known, the political and social strategies of the late colonial government offered many points of purchase for these pervasive forms of caste assertion, and the latter constituted one of the major social legacies of the colonial state to independent India's first governments.

These are now very familiar forces. Yet there is a danger that the very salience of 'ethnicized' caste and identity politics in the public life of our modern era will lead us to overlook the longer term continuities described above, and the sometimes obscure colonial intellectuals who wrestled with them. Intellectuals such as Padval, and his predecessors in the eighteenth century and before, were sharply aware of this long history. They worried about texts and their very material influence, understood the dignities of Vedic ritual, identified varna status as a key part of social prestige, and appreciated-and sometimes deeply deplored-the power of stigmatization that might follow if these dignities were withheld.

Their critiques certainly drew on the intellectual resources that became available under colonialism, but were no mere by-products of colonial knowledge. What is valuable about their engagement with western India's long tradition of argumentation about caste is that it reminds us that caste, as explicit or implicit hierarchy, is-and has always been-very much more than an epiphenomenon of the state, and sustained strongly in the domains of family and personal life, bodily comportment, and religious practice.

${ }^{88}$ Keśava Trimbak Gupte, Rājavāadyācī Gāgābhațtī. Pune: Indu Prakash Press, 1919, p. 42 . 